\title{
REPRESENTACIONES VISUALES DEL PODER EN ÉPOCA \\ TARDOANTIGUA: LA IMAGEN DE LA EMPERATRIZ
}

\author{
POR \\ MAR MARCOS \\ Universidad de Cantabria
}

\begin{abstract}
RESUMEN
En Roma, las mujeres estaban excluidas de las funciones públicas y las emperatrices no eran en ello un excepción. Ahora bien, aunque en el sentido estrictamente legal carecían de poder, sí participaban en el mundo de la política. El objeto de este artículo es estudiar el papel dc las emperatrices tardoantiguas en la política de creación de consenso, que contribuía a mantener al emperador en su puesto y a justificar la continuidad de su linaje. Las imágenes de las emperatrices en la literatura (panegíricos, oraciones fúnebres) y en el alte (monedas, escultura, mosajcos etc.) serán analizadas aquí como medios de propagación de la ideología imperial.
\end{abstract}

\section{ABSTRACT}

Roman women were excluded from public office and empresses were not an exception. However, although they had no constitutional power did participatc in politics. The aim of this article is to analyse the role of late-antique cmpresses in the policy of creation of consensus, intended to mantain the emperor in his place and justify the continuity of his family. The images of empresses in literature (panegyrics, funeral speeches) and art (coins, sculpture, mosaics, atc.) will be study here as effective vehicles of propagating imperial ideology. 
Princeps legibus solutus est: Augusta autem licet soluta non est. Principes tamen eadem illi privilegia tributunt, quae ipsi haberent ${ }^{\prime}$.

Desde el punto de vista legal, las emperatrices romanas carecían de cualquier autoridad. La ley y la costumbre en Roma no autorizaban a las mujeres a desempeñar funciones públicas y la esposa del emperador -él mismo durante mucho tiempo considerado un ciudadano más - no era una excepción. Aunque a lo largo del Imperio existieron múltiples ejemplos de emperatrices que demostraron que era posible intervenir en los asuntos de gobierno, su status legal en este sentido nunca se modificó. A mediados del siglo $\mathrm{V}$, la corte de Valentiniano III respondía negativamente a las reclamaciones dinásticas de la hermana de éste, porque, se argumentaba, "el gobierno del imperio pertenece a los hombres, no a las mujeres"

Pero los aspectos institucionales no son los únicos que definen y conforman el poder del emperador romano. Su permanencia a la cabeza del estado depende de la legitimidad, pero también de otros factores, fundamentalmente el apoyo de las élites, de quienes se extraía el aparato burocrático, y, muy importante, el apoyo del ejército. El éxito del príncipe dependía, en última instancia, del consenso de los súbditos. Estos debían ser persuadidos de que su gobernante era el más apto para esa función: un hombre excepcional, en cuya figura se resumían las principales virtudes personales y cívicas, capaz de garantizar la paz y la continuidad del Imperio y destinado a regirlo por sus cualidades casi divinas ${ }^{3}$. En el Bajo Imperio el principio de autoridad se había reforzado y la ideología del poder se perfilaba con trazos nuevos. El emperador se presenta como un monarca y su persona era más sacrosanta que antes. Si bien seguía dependiendo de la burocracia y el favor del ejército, había dejado de pertenecer al común de los mortales: era el elegido de Dios, su vicario en la tierra, destinado a perpetuar un nuevo imperio cristiano.

La ideología imperial se propagaba por canales variados. En el Bajo Imperio los signos externos de la monarquía adquirieron un valor simbólico excepcional. La arquitectura del palacio y la propia presencia del emperador, distante y envuelta en el misterio, la complejidad del ritual de corte comunicaban mensajes visuales a quienes tenían la oportunidad de ver al príncipe; los panegíricos, leídos en público y editados, liegaban a una audiencia más amplia; las imágenes, en fin, del emperador circulaban bajo el control de la corte

\footnotetext{
Itpiano, I, 3, 3i.

2 Prisco, Frag. 15. Para la interpretación del episodio, vid. K.G. Holum, Theodosian Empresses. Women and Imperial Dominion in Late Antiquity, Berkeley-Los Angeles-Londres, 1982, p. I ss.

${ }^{3}$ Vid. A. WaLlaCe-HaDRilL, "The Emperor and His Virtues", Historia 30 (198!) 298-319.

La Personalidad Internacional de los Papas Hispania Sacra 48 (1996)
} 
por todo el imperio en los soportes más heterogéneos: representaciones en las monedas, pinturas y esculturas que se colocaban en plazas y edificios oficiales, retratos bordados sobre vestidos, imágenes que acompañaban al ejército, piezas de vajilla...

La emperatriz carecía legalmente de poder, pero, como señala el jurista Ulpiano, participaba del poder del príncipe. Si generalmente no ejercía en el sentido estricto funciones de gobierno, sí participaba en "política". El objeto de esta comunicación es mostrar el papel de las emperatrices tardoantiguas en la política de creación de consenso que contribuía a mantener al emperador en su puesto y a justificar la continuidad de su linaje. Todo ello a través del lenguaje de las imágenes. Imágenes literarias y visuales que se presentaban a los súbditos en formas semejantes, y en prácticamente los mismos soportes que la de los emperadores: panegíricos y oraciones fúnebres, inscripciones, monedas, escultura, mosaicos, pintura, objetos de adorno personal y orfebrería.

Organizamos el estudio en dos partes, que tienen que ver con los conceptos de "tradición" e "innovación". En la primera, estudiamos el uso y la función de la imagen de la emperatriz en sus roles tradicionales, heredados del Alto Imperio, como medio de legitimación y propaganda dinástica. Esto es, como esposa y madre del emperador, garante de la estabilidad y la pervivencia del imperio. En la segunda parte, trataremos de innovaciones para ocuparnos de la nueva imagen de la emperatriz-Augusta, copartícipe del poder y sus signos externos, una imagen que es producto y reflejo de los cambios introducidos en la mentalidad tardoantigua.

\section{LEGITIMACIÓN, CONSOLIDACIÓN Y CONTINUIDAD DINÁSTICA}

Uno de los aspectos que nunca estuvo regulado en el Imperio fue el criterio de transmisión del poder. El emperador designaba a su sucesor, generalmente entre sus descendientes directos o algún miembro de la familia, pero el principio hereditario nunca se había formulado como tal. Tras la dinastía de los Severos, durante el siglo III fue principalmente la voluntad del ejército la que elegía emperador. Diocleciano instauró un sistema de reparto y transmisión del poder en el que no contaba la herencia - aunque no estaban excluidas las conexiones dinásticas-, que demostró ser muy inteligente y eficaz mientras duró, es decir, unos diez años en su diseño original. En el 310 un panegirista de Constantino manifestó públicamente lo que nadie antes se habría atrevido a declarar en térmitos tan explícitos: "No ha sido el acuerdo accidental de los hombres ni un soplo súbito del favor lo que ha hecho de ti un príncipe: mereciste el imperio en virtud de tu nacimiento (...) Tú no entraste en este sagrado 
palacio como un candidato al imperio, sino como un emperador designado e inmediatamente los lares paternos vieron en ti al legítimo sucesor. Estaba fuera de duda que la herencia debía corresponder al primer hijo que los hados le habían otorgado al emperador"4. Quedaba sentado el valor primordial del principio hereditario, y así permanecerá en las generaciones siguientes. Lo cual no implicaba, no obstante, que fuera fácil obtener consenso sobre quién debía ser el sucesor y cuál la porción del Imperio que le correspondía regir. A partir de Constantino la familia del emperador, y con ella las mujeres, pasa a ocupar de nuevo un lugar muy importante y retoma sus viejas funciones en la imaginería y la propaganda de la corte.

$$
\text { * * * * }
$$

El 31 de marzo del 307 Constantino asistió a uno de los días más ceremoniosos de su vida: contraía matrimonio con Fausta, la hija menor del tetrarca Maximiano, y era investido por su suegro con el rango de Augusto ${ }^{5}$. Se pronunció entonces un discurso, mitad panegírico mitad epitalamio, que celebraba ambos acontecimientos como si se tratara de una feliz coincidencia [Paneg. 6 (7)]. La boda - era un hecho evidente para cualquier contemporáneo al tanto de la evolución de los acontecimientos de los últimos tiempos- respondía a razones políticas y el panegírico, en realidad, conmemoraba la alianza entre Constantino y su suegro ${ }^{6}$. Maximiano, que había retomado ilegalmente el poder al igual que su hijo Majencio, autoproclamado Augusto en Roma en 305, daba en matrimonio su hija a Constantino, que había sido también elevado de forma irregular por el ejército de Britania, y le ofrecía el reconocimiento como Augusto que hasta entonces se le había negado. Occidente se hacía así fuerte a la espera del ataque de Galerio, el Augusto de Oriente, el único designado conforme a la legalidad, tal y como ésta había sido establecida por Diocleciano.

El panegirista del 307 conocía, por supuesto, las circunstancias de este matrimonio y sin embargo introdujo en el discurso un toque romántico, aunque cargado de significado político: Constantino y Fausta se habían amado

\footnotetext{
s La fecha del matrimonio no puede establecerse con seguridad. Generalmente se sitúa en marzo del 307 (E. Galletier, Panégyriques Latins, Il (París, 1952), aunque se han propuesto dataciones alternativas. Así, por ejemplo, el gran estudioso de Constantino T.D. BARNES, JRS 63 (1973) 41, n.143, propone el final del verano o el oton̄o de ese año.

6 Los autores antiguos incluyen la noticin en el marco de las complejas manipulaciones políticas que sucedieron al regreso de Maximiano al poder. Asf, principalmente, Lactancio, De mort,pers., 27, 1 (aunque el pasaje está muy cortupto) y Zósimo, II, 10,6.
} 1969).

4 Paneg. 7 (6), 3, 1; 4, 1-2 (Trad. V.J. Hersero y F.P. de Samaranch, Exl. Aguilar, Madrid, 
desde niños. La prueba: un mosaico de uno de los comedores públicos del palacio de Aquileya en el que se representaba a Fausta ofreciendo a Constantino niño un casco de oro y piedras preciosas rematado con plumas, como regalo de bodas ${ }^{7}$. Si el hecho es cierto, y el cuadro representaba lo que se dice $^{8}$, ello implica la existencia de un plan premeditado hacía años, que, por otro lado, no sorprendería a nadie: las alianzas dinásticas, una práctica tan antigua como el Imperio, habían servido para reforzar los lazos que unían a los tetrarcas, e incluso habían anticipado la cooptación de sus césares ${ }^{9}$. La ceremonia del 307 se presentaba así, no como lo que realmente era —el sello de un acuerdo político- sino como la ejecución en un momento muy propicio de viejas previsiones de las que era testimonio el mosaico, un soporte duradero para dar publicidad a un compromiso que, vista la corta edad de los contrayentes, debía esperar años para materializarse.

Una vez celebrada la boda, nuevas imágenes - esta vez de interpretación segura - vinieron a dar publicidad al acohtecimiento. Se acuñaron monedas de plata conmemorativas con la efigie de Fausta, con el título nobilissima femina (el que llevan las mujeres de la casa imperial que no son augustas) en el anverso y con dos tipos de reverso alusivos al matrimonio: Juno, la diosa protectora de las mujeres, y sobre todo de las casadas en su calidad de Pronuba, y Venus, la diosa del amor. La emisión debió de ser contemporánea a la de una serie de monedas de plata de Tréveris celebrando el ascenso de Constantino al augustado ${ }^{10}$.

Conmemorar un matrimonio imperial con una emisión de monedas no era excepcional. Ahora bien, en el caso de Fausta el hecho tiene una cierta relevancia, puesto que, que sepamos, ninguna de las mujeres de la tetrarquía en Occidente fue conmemorada en las series monetales, ni tal vez distinguida con el título de Augusta, que Fausta recibirá años más tarde. Quizá porque ninguno de sus matrimonios encerraba un significado tan crucial como éste". Ahora bien, todos los ejemplares que se han hallado de las monedas conmemorati-

\footnotetext{
7 Paneg. 6(7), 6, 1; Orig.Cons. 2.

"En un artículo reciente, J.W. DRIvJERs, "Flavia Maxima Fausta: Some Remarks", Historia 4l, 4 (1992) 500-506, reconsidera la realidad de este compromiso matrimonial, generalmente aceptado por los historindores, y concluye que es muy probable que éste no llegara a formalizarse.

9 Constancio Cloro se había casado con Teodorn, hija de la esposa de Maximiano de un matrimonio anterior antes de que aquél fuera nombrado Augusto, y cs probable que de la misma forma lo hiciera Galerio con Galeria Valeria, la hija de Diocleciano. Vid, T,D, BARNES, Constantine and Eusebius, Harvard Univ. Pr., 1981, pp.8-9.

10 Cfr. K.J. GilLes, "Ein unbekannte Hochzeitsprägung der Fausta aus Trier", en Funde und Ausgrabungen im Bezirk Trier, 18 (Kurtrierisches Jahrbuch, 26, 1986), Tréveris, 1986, 44*-47*.

I" El título de Augusta está atestiguado sólo para Galeria Valeria, la esposa de Galerio, en cuyo honor se acuñaron monedas. Vid. PLRE, p. 937.
} 
vas del matrimonio proceden de la ceca de Tréveris. A pesar de la resonancia universal de esta unión, que proclamaba el panegirista al comienzo mismo de su discurso ${ }^{12}$, el hecho muestra la precariedad en ese momento de la posición de Constantino, que tendrá que esperar tres años para ser reconocido Augusto por Galerio.

La propaganda del matrimonio de Fausta es un arquetipo de lo que, siguiendo la tradición, se convirtió en práctica habitual en el proceso de trans* misión de poderes en el Bajo Imperio. Constantino fue un maestro en el uso de las mujeres de la familia para sellar sus decisiones políticas. Su hermana Constancia fue otorgada en matrimonio a Licinio en el 313 en Milán, una unión que se interpretó en su tiempo, y en la tradición historiográfica posterior, como el sello de los acuerdos alcanzados entonces entre ambos augustos $^{13}$. Según Eusebio de Cesarea, este matrimonio concedía a Licinio lo que de otra forma no podría adquirir: la nobleza ancestral y la antigua sangre imperial, que le daba derecho a compartir el poder con Constantino ${ }^{14}$. Siguiendo su estrategia de controlar el máximo de poder, Constantino trató de convencer a Licinio del nombramiento de un César para gobernar Italia: el candidato propuesto era Basiano, el marido de su hermana Anastasia ${ }^{15}$; el otro César sería su hijo Crispo, reproduciendo así en apariencia el esquema de Diocleciano. Fausta no tuvo hijos hasta el 316. Mientras tanto, hacia el 315 había nacido un hijo de Licinio y Constancia: si se aceptaba a Basiano como César el hijo de Licinio no llegaría a serlo ${ }^{16}$. Pero el caso más espectacular de esta política de uniones dinásticas fue, sin duda, el de su hija Constantina. Contrajo un primer matrimonio con Hanibaliano y a continuación éste fue nombrado por Constantino "rey de reyes" para ocupar el trono del Ponto y Armenia ${ }^{17}$; viuda a consecuencia de la masacre del 337, fue pedida en matrimonio (c.350) a su hermano Constancio por Magnencio para dar legitimidad a su situación de usurpador ${ }^{18}$; finalmente Constantina contrajo segundas nupcias con otro pariente cercano, Galo César ${ }^{19}$. Mientras tanto, Constancio II se había casado con una hija de su tío Julio Constancio, el padre de Juliano y Galo, y como

\footnotetext{
$126(7), 1,3-4$

13 Según Lactancio, Maximino Dayn comprendió enseguida el significado de esta unión y la interpretó como una amenaza, De mort.pers. 43,$2 ; \mathrm{cfr} .45,1$.

14 Eus. $H E \mathrm{X}, 8,4$; cfr, Vit. Const. I, 49.

is Anon. Val. $5,14$.

I6 Asî interpreta la propuesta de Constantino T.D. BARNES, op. cìt. (1981) p.66.

17 Anon. Val., 6, 35: Hannibalianum, dafa ei Constantina filia sua, regem regum et Ponticarum gentitun constituit; Aur. Victor, Epit. 41, 20. Según Filostorgio IIl, 22, 28 -futente única- Constantina fue nombrada Augusta por su padre.

18 Chron. Pasch. o. 350.

14 Amm. Marc. XIV, 1, 2.

La Personalidad Internacional de los Papas Hispania Sacrn 48 (1996)
} 
parte del ceremonial del nombramiento de Juliano césar se incluía el matrimonio con la hermana del emperador, Helena ${ }^{20}$.

La estrategia de alianzas dinásticas pervivió en las siguientes generaciones. Durante años permaneció vivo el deseo de los emperadores de hallar conexiones con la familia de Constantino el Grande. Avanzado el siglo, y cuando ya la dinastía valentiniana estaba consolidada, el emperador Graciano se casó (c.374) con la que debía ser la única heredera directa superviviente de la casa de Constantino, Constancia, la hija póstuma de Constancio II. Un matrimonio que fue celebrado en Roma con la dedicación de estatuas (stelai) de plata ${ }^{21}$ y que permitía alardear a Graciano de su nuevo status familiar: con ocasión del consulado de su maestro Ausonio el emperador le regaló una trabea en la que, como se encarga de recordar Graciano mismo, estaba bordada la imagen de su padre, el divino Constancio ${ }^{22}$. Una vez muerto Graciano, Teodosio hizo trasladar a Constantinopla los restos de esta princesa — que ya hacía años que había muerto- para ser enterrados en el mausoleo familiar de la Iglesia de los Apóstole ${ }^{23}$, donde luego iba a descansar él mismo y los emperadores de su dinastía. También Teodosio se preocupó de resolver su carencia original de lazos de sangre con la dinastía valentiniana. Cuando accedió al poder en 379 estaba ya casado, pero su mujer Flaccila murió en 386 ó 387 . Unos meses más tarde la familia de Valentiniano I, entre ellos su hijo Valentiniano II, el Augusto de Occidente, se refugiaba en Tesalónica huyendo de la invasión de Italia por Máximo. Teodosio se casó entonces con una de las princesas, Gala, una arriana como su madre, la emperariz Justina, para lo que el muy ortodoxo emperador de Oriente debió pasar por encima de sus escrúpulos religiosos ${ }^{24}$.

No tenemos imágenes de la publicidad de estas uniones, aunque debieron existir. Hay una laguna inexplicable en las representaciones de mujeres de la casa imperial desde la época de Helena y Fausta hasta Flaccila: no se han hallado inscripciones, ni monedas ni estatuas de atribución cierta. Se suele aducir como justificación el hecho de que, según parece, ninguna mujer desde

\footnotetext{
211 Amm. Marc. XV, 8.

21 Parastesis, 50 (Ed. Preger, 54). Cfr. R.H.W. STICHEL, Die Rönische Kaiserstatue am Ausgang der Antike, Roma, 1982, p. 76.

22 Gratiarum actio, ] 1: dives Constantius parem noster intextus est.

${ }^{23}$ El cuerpo se trasladó a Constantinopla el 12 Sep. del 383 y fue enterrado el I Diciembre del mismo año: Chron, Pasch. s.a. 383. Cfr. R. GRIERSON, "The Tombs and Obits of the Byzantine Emperors (337-1042)", Dumbarton Oaks Papers 16 (1962) 1-64, espec. p.25.

24 Las circunstancias de este matrimonio las describe Zósimo, 1V, 44. Antes de la boda Gala debió de renunciar públicamente al arriantsmo, por orden de Teodosio, como hizo Valentiniano II: Teodoreto de Ciro, V, 15 .
} 
Constantino a Teodosio fue honrada con el título de Augusta ${ }^{25}$. Sin embargo, aunque éste es un motivo de peso -que explicaría, por ejemplo, la ausencia de monedas- no es suficiente. Hemos aludido antes a las estatuas erigidas en Roma en honor de Graciano y Constantina; sabemos, por otra parte, que unos años antes Juliano utilizaba las estatuas de su esposa Helena como instrumento de propaganda de su política religiosa. Recuperando la costumbre de representar a la emperatriz bajo la efigie de una divinidad, había hecho instalar en Nicomedia una estatua de Apolo y otra de Ártemis, que, como imágenes sagradas que eran del emperador y la emperatriz, recibían el culto de todos los habitantes de la ciudad, incluidos los cristianos ${ }^{26}$. La vieja práctica de representar a la emperatriz bajo la efigie de divinidades, con lo que se subrayaba la estrecha relación de éstas con la casa imperial, había desaparecido en el imperio cristiano. Se conservaba, no obstante, la asociación con personificaciones de virtudes - las más frecuentes Pietas, Salus, Securitas y Pax- cuyas imágenes estaban tan asociadas.a la iconografía imperial que no podían suscitar ningún recelo.

Estatuas de la pareja imperial debieron propagarse, pues, por el Imperio, en Oriente y en Occidente, durante todo el siglo IV. La dinastía teodosiana, profusa en imágenes, supuso un revival de esta práctica tradicional. En Oriente la familia logró sobrevivir sin grandes tumultos durante casi tres cuartos de siglo, uno de los períodos más largos de toda la historia del Imperio. Sin embargo, en Occidente la situación, agravada por las invasiones, fue más difícil.

El camafeo Rothschild representa a una joven pareja imperial. Él lleva una diadema de doble hilera de gruesas piedras preciosas y en la mano derecha el cetro del Imperio. La mujer no porta ningún signo de distinción: viste una túnica al modo clásico y sujeta el peinado - una mezcla de estilos clásico y moderno- con una diadema, probablemente una corona nupcial. Principalmente por razones de estilo se identifica a la pareja con Honorio y María (quien nunca recibió el título de Augusta), que contrajeron matrimonio en el 398 en Milán, siendo muy jóvenes ${ }^{27}$. El poeta de la corte y propagandista

${ }^{25}$ Esta es una opinín generalizada. No obstante, Filostorgio, III, 22 y 28 , dice que Constancia, la hija de Constantino, recibió este título de su padre. Malalas, 13, llama Augusta a Marinn, la primera esposa de Valentiniano 1, y Jordanes, Rom. 314, da este título a Dómnica, la esposa de Valente. Ahora bien, puesto que las dos últimas fuentes son muy tardías pueden estar reflejando realidades de su época, cuando, sobre todo en Oriente, el título de Augusta era normal para las emperatrices.

26 Orig. Const. (Th. Preger, p. 53, 3). Cfr. Soz. V, 17, 2.

${ }^{27}$ R. DELBRÜCK, Spärantike Kaiserporträts von Konstantinus Magnus bis zum Ende des Westreichs, Berlín-Leipzig, 1933, pp. 206-207 (guien pone de selieve la semejanza entre este retrato y el del emperador en el Díptico de Probo del 406), siguiendo a G. BATTAGLIA, "11 cameo d'Onorio e Moria e gli avori profani classicheggianti della tarda età romana", BullCom 59 (193!), 131 ss. La

La Personalidad Internacional de los Papas Hispania Sacra 48 (1996) 
oficial de la casa de Estilicón, Claudiano, escribió cuatro Fescenios y un Epitalamio para conmemorar la unión. Los poemas, como todos los suyos, encierran un alto significado político. En el Epitalamio, Claudiano se esfuerza por dar una explicación airosa a estas nupcias, inusualmente tempranas. Honorio, se dice, ardía en deseos de casarse con la hija de su tutor Estilicón y de su hermana adoptiva Serena, con la que se había criado en palacio; la iniciativa del matrimonio, enfatiza el poeta, había partido del joven príncipe, quien esperó ansioso la respuesta del padre de la novia ${ }^{28}$. La realidad, en cambio, era bien distinta. Son conocidas las aspiraciones de Estilicón respecto al imperio $^{29}$. Teodosio le había nombrado tutor de Honorio y, según decía el mismo Estilicón, aunque de esto no había ningún testigo, también del otro heredero, Arcadio, el Augusto de Oriente. La función de guardián de la seguridad del linaje imperial se amplificó enseguida para incluir a sus propios descendientes: sus dos hijas, María y Termancia, y su hijo Euquerio. La principal fuente de autoridad de Estilicón - aparte de sus cualidades militares, no siempre bien demostradas - era su parentesco con la familia de Teodosio a través del matrimonio con Serena, sobrina predilecta e hija adoptiva del emperador. Claudiano aprovechaba cada ocasión para recordar que la sangre imperial corría por las venas de sus hijos, pero eso no era suficiente para reclamar el trono cuando había dos emperadores legítimos y jóvenes. El único medio honroso de asegurar el acceso al imperio de sus hijos era la unión de éstos con los descendientes directos del fundador de la dinastía. La precipitada boda de Honorio con María era el primer paso en este sentido, en un momento en que la posición política de Estilicón no era muy firme ${ }^{30}$.

\footnotetext{
identificación no es segura. pero es mís acertada, sin duda, que la que propone a Constancio ll y "su emperatriz" (?): J. BECKwITH. Eatly Christian and Byzantine Art, Londres, 1970, p. 79. El poeta Claudiano, De mip.Hon. II, ss. dice que el día de la boda María recibió las insignias del poder, conservadas en el tesoro imperial desde Livia. Pero, puesto que no fuc elevada al rango de Augusta, la emperatriz no exhib́a estos śmbolos en los retratos oficiales. En el 398 Honorio tenía 15 años y María 13.

${ }^{24}$ Epith. I ss.

${ }^{29}$ Para estos aspectos y las líncas que siguen, vid. especinlmentc A. CAMERON, Claudian. Poetry and Propaganda at the Court of Homorits, Oxford, 1970.

3i" Claud. Fescen. II: gener augusti pridem fueras

none rursus eris socer Augusti.

quae iam rabies livoris erit?

vel quis dabitur color invidiae?

Stilico socer est, pater est Stilico.

Después de esta boda, como nota A. Cameron, słp.cit., pp. 56 ss., Serena ya no es llamada "hermann" de Honorio en los poemas sino "suegra", a la vez que es muy frecuente el uso de "suegro", junto a "yerno", para reforzar la relación de Estilicón con los teodosianos.
} 
En el año 400, Estilicón celebraba su consulado y aprovechó la oportunidad para expresar plásticamente sus sueños dinásticos. En los versos de Clauldiano pronunciados para la ocasión era Roma quien ofrecía al nuevo cónsul la toga en la que Minerva había bordado la siguiente escena: en un palacio con columnas de mármol rojo (un color que en el Bajo Imperio se había convertido en uso exclusivo de la familia imperial) se veía el "sagrado" parto de la emperatriz María. En otra escena, el niño, que guarda un gran parecido con su padre, está ya crecido; Estilicón, maduro en años, enseña a su nieto la ciencia de la guerra. En otro lugar se representa a Euquerio joven a caballo en una escena de caza. Aparece en escena Venus, que "une por tercera vez en su carro la familia del héroe (Euquerio) con la casa principesca"; amores alados portan a la novia, hija y hermana de un emperador (no podía ser otra que Galla Placidia) y levantan el velo de su cara mientras Termancia, la última de los hijos, sonríe ante la alegría de su hermano ${ }^{31}$. Unicamente la pequeña Termancia queda al margen de la trama dinástica, pero sólo porque no había para ella un príncipe disponible. No es improbable, sin embargo, que en algún momento Estilicón y Serena hubieran planeado su matrimonio con Arcadio. En los primeros versos del Epitalamio, Claudiano alaba la elección de la novia que ha hecho Honorio quien, se dice, a diferencia de otros "príncipes lujuriosos que buscan las bellezas a través de retratos, que van pasando de casa en casa", conocía a su esposa desde siempre ${ }^{32}$. Alan Cameron ${ }^{33}$ relaciona esta alusión con el odio de Estilicón a Eutropio, quien, según un conocido pasaje de Zósi$\mathrm{mo}^{34}$, había despertado el interés de Arcadio por su futura esposa, Eudoxia, a través de un cuadro. Para el año 400 esta boda ya se había cumplido.

En el momento de la entrega de la toga, Roma había hecho a Estilicón el siguiente váticinio: "Pronto me reconocerás como una verdadera profeta y el destino futuro probará que mi bordado es real". Todos los augurios fueron desgraciadamente equivocados: María nunca llegó a engendrar un hijo de Honorio; ni tampoco garantizó la púrpura Termancia, casada con éste tras la muerte de su hermana; Euquerio corrió la misma suerte que su padre y su madre, el asesinato, mientras Gala Placidia, destinada a perpetuar la dinastía en Occidente, se casaba con Ataúlfo.

$$
* * *
$$

Tras el matrimonio, la maternidad era el acontecimiento más importante en la vida de la emperatriz. No tener hijos se consideraba un gran infortunio para

3 Stil. II, vv. 335 ss.

32 Epith. 20 ss.

"3. Op.cit.pp. 53-4.

$34 \mathrm{~V}, 3,3$.

La Personalidad Internacional de los Papas Hispania Sacra 48 (1996) 
cualquier mujer romana, y especialmente para la esposa del emperador. Un varón suponía la garantía de la pervivencia del linaje y se festejaba como una ocasión de júbilo en todo el Imperio. El nacimiento del hijo del César Crispo y Helena - lo sabemos, como tantas veces, por una noticia casual- fue celebrado, según era costumbre en los grandes momentos, alegres y trágicos, de la vida de la corte con una indulgencia general a homicidas y adúlteros ${ }^{35}$. Garantizarse un descendiente importaba hasta el punto, como hemos visto en el caso de la familia de Estilicón, de anunciar embarazos ficticios.

Cualquier motivo era bueno para alabar la maternidad de la emperatriz o para lamentar la desgracia de su falta de éxito en esta función ${ }^{36}$. El emperador, por su parte, se mostraba a menudo en público y se hacía representar en compañía de sus hijos, en mensajes de asociación al trono que eran fáciles de captar. El lenguaje de las imágenes colaboraba eficazmente en la difusión de estas ideas. Uno de los vehículos de propaganda de mayor alcance eran las monedas. Durante el Alto Imperio fue una práctica común honrar con ellas a las mujeres que habían disfrutado del reconocimiento especial del emperador (esposas, madres, hijas, etc.) y así se siguió haciendo en época tardoantigua. Los anversos son prácticamente invariables: se representa el busto de la emperatriz de perfil con una leyenda que incluye bien su nombre completo o sólo el cognomen, y su título. Los reversos son más variados y mucho más interesantes en cuanto que encierran significados, desde el punto de vista propagandístico, muy ricos y a veces muy sofisticados. Cuatro leyendas, con sus respectivas personificaciones en las que habrá que reconocer a la emperatriz, dominan en la iconografía: SECVRITAS REIPVBLICAE, PIETAS PVBLICA/AVGVSTA, SALVS REIPVBLICAE y SPES REIPVBLICAE, todas alusivas a la función de la emperatriz como protectora y sostén de la dinastía. Con alguna de estas leyendas -que no son exclusivas de las mujeres, sino que son también de uso normal en los reversos de los emperadores- tenemos ejemplares de todas las emperatrices en cuyo honor, que sepamos, se acuñaron monedas $^{37}$.

3 CTh IX, 38, I (322)

${ }_{36}$ Vid., por ejemplo, las alabanzas a la emperatriz Flaccila en su papel de madre de futuros emperadores por el obispo Gregorio de Nisa, Orat. Flacc. PG 46, 892; o el tamento de Juliano por la incapacidad de Eusebia de dar hijos a Constancio II: Orat. ad Athen. 271 y 275 . Las intrigas de la misma Eusebia para evitar, reiteradas veces, que ljegara a nacer un sucesor de Juliano son buena prueba de esto (Amm. Marc. XVI, 10, 18).

"7 Helena, Fausta, Constancia (hermana de Constantino), Flacila, Eudoxin (esposin de Arcadio), Pulqueria, Gala Placidia, Eudocia (esposa de Teodosio II), Justa Grata Honoria (hija de Gala Placidia) y Licinia Eudoxia (hija de Teodosio II y esposa de Valentiniano III). Sería inteminable aportar una lista completa de las referencias de estas monedns. Remitimos, como ya es tradicional, a los catálogos de Cohen, RIC Vll ss., y en particular a J.W. DRJJVERS, Helena Augusta, Leiden, 1992, 
Invariablemente, cada dinastía ponía en circulación imágenes que hablaban del bienestar de su época y cada una se autoproclamaba como la mejor garante de la pervivencia del Estado. La presentación adecuada de los herederos era fundamental para asegurarse el monopolio en la tarea de perpetuar la felicidad de los tiempos. El ejemplo más ilustrativo en el Bajo Imperio de este uso de las imágenes familiares en la política sucesoria lo proporciona el gobiemo de Constantino. Desde el origen mismo de su reinado los panegíricos enfatizan el aspecto dinástico del poder imperial a la vez que se propagaba la idea de que naturalmente Constantino sería sucedido por sus hijos ${ }^{38}$. Los dos mayores, Crispo y Constantino II, fueron nombrados Césares en 317, con ocasión del tratado de paz con Licinio. Con la supresión de éste último en septiembre del 324 Constantino acababa con todos sus rivales. Menos de dos meses más tarde, el 8 de noviembre del 324, es nombrado César en Nicomedia su tercer hijo, Constancio II, y con toda probabilidad en la misma fecha y lugar fueron elevadas al rango de Augustas Helena y Fausta ${ }^{39}$.

Distintas ernisiones monetales, que comentaremos enseguida, presentan a la familia como una dinastía, mientras que retratos de grupo debieron repartirse, como era tradicional, por las provincias. Ninguno de estos grupos escultóricos se ha conservado y pocas de las estatuas de hombres y mujeres de época constantiniana se pueden identificar con certeza ${ }^{40}$. Por fuentes bizantinas tardías sabemos que Constantinopla fue durante toda la época bizantina un escenario lleno de imágenes imperiales, una práctica que había iniciado su fundador Constantino.

Un cierto número de investigadores ha reconocido a la familia en el Camafeo Ada (Stadtbibliothek, Tréveris), donde, según la opinión autorizada de Andreas Alföldi, estarían representados, de izquierda a derecha, Helena,

para Helena y Fausta y K. HolUM, op.cit. para las emperatrices teodosianas, donde se podrá hallar otrn bibliografía específica.

3* Cfr. Paneg. 6, 3, 3: Constantino heredaba cl poder de su padre; 7,4,2 (del 310), descendencia de Claudio el Gótico; Panćg. 8, del 313: semejanza con su padre; Paneg. 9, 26, 4 ss. (313): Constantino sería sucedido por Crispo.

39 Vid. Brunn, RIC, VIt. En contra J.W. DRIJvers, op.cit. (1992), p. 4I, n.10, quien mantiene que la clevación de Helena es anterior a la de Constancio 11.

4' Cfr. como obra de referencia obligada, aunque muchas de sus atribuciones son discutidas, R. DelbrüCK, Spätantike Kaiserportritts von Konstantimus Magnus bis zum Ende des Westreichs, Berlín-Leipzig, 1933. Los testimonios sobre las estntuas de Constantino y sus succsores cstán recogidos en R. CALzA, lconografia romana imperiale da Caraurio a Giuliano (287-363 d.C.) Roma, 1972 (con catálogo e ilustraciones de los retratos). Para las imágenes de las mujeres de la dinnstía el cotálogo más completo lo ofrece M. WEGNER, "Frauen der Tetrarchen, des Constantinus und dessen Familie". en Das rönische Herscherbild. Diokletian bis zum den Konstrmin-Sihne (H.P. L'Orange), Berlín, 1984, pp.14l ss., quien pone constantemente de manifiesto la incertidumbre en la atribución de cada uno de los retratos.

La Personalidad Internacional de los Papas

Нікраліа Sacra 48 (1996) 
Constantino I, Constantino II, Fausta y Crispo ${ }^{41}$. Mucho más discutido es el Camafeo de Leiden (Koninklijk Penningkabinet), donde se representa a una pareja imperial sobre un carro tirado por centauros, que pisotean a dos enemigos; una Victoria ofrece al emperador una corona de laurel, mientras otros dos personajes asisten a la escena: un niño con traje militar y, detrás del emperador, una mujer con corona de laurel. Si el camafeo es de principios del siglo IV, la pareja imperial podría representar, bajo rasgos divinos, a Constantino y Fausta y el niño sería Crispo. No hay acuerdo en la identificación de la mujer del fondo (¿Helena?). En cualquier caso, el camafeo debe ser anterior al $324^{42}$. Un medallón de bronce de Nantes con el monograma cristiano que muestra una pareja con tres niños ha sido también interpretado como un retrato de Constantino, Fausta y sus tres hijos mayores, Constantino II, Constancio y Constante ${ }^{43}$. De interpretación también controvertida son las pinturas del techo del palacio constantiniano de Tréveris. El panel estaba dividido en 15 cuadrantes, con retratos de hombres, mujéres y putti. A diferencia de los hombres, las mujeres llevan el nimbo, que, como se sabe, Constantino introdujo en su iconografía y en la de los miembros de su familia asociados al poder. La cronología es segura, el primer cuarto del siglo IV, pero no así la identificación de los personajes. Th.K. Kempf, que publicó el hallazgo en 1950, reconocía en las mujeres retratos de la casa de Constantino ${ }^{44}$. A partir de su publicación las pinturas han sido objeto de múltiples estudios, cuyos resultados, sin embargo, no son muy dispares: hay quienes creen, siguiendo a A. Alföldi ${ }^{45}$, que las pinturas son retratos (Helena -la mujer de Crispo-, Helena -la madre de Constantino-, Fausta y Constantina), pero con un significado simbólico (laetitia publica, hilaritas populi romani); hay quienes mantienen, siguiendo a M.R. Alföldi ${ }^{46}$, que las figuras son alegóricas y que hacen referencia a una boda imperial, la de Crispo y Helena; hay quienes defienden, en fin, el carác-

41 A. ALFOLd, "Der grosse römische Kameo der Trierer Stadtbibliothek", Trierer Zeitschrift 19 (1950) 41-44. Tanto la fecha como la identilicación de los personajes ha sido muy discutida. Vid. una síntesis de las distintas opiniones con referencias bibliográficas en J.W. DRHVERS, op).cit. (1992), pp. 191-192.

42 Vid. discusión, con bibliografía, en Spätantike und frihes Christentum, Frankfurt am Main, 1983 , pp. 435-437.

43 Vid. M. WeGNer, op.cit., \$.v. "Flavia Maxima Fausta", p. 153.

44 TH.K. KEMPF, "Konstantinische Deckenmalereien aus dem Trierer Dom", frierer Zeitschrift $19(1950)$, p.51.

4.5 "Zur Erklärung der konstantinischen Deckengemälde", Hisforia 4 (1955) |3|-|50.

4o "Helena Nobilissima Femina. Zur Deutung der Trierer Deckengemïlde", Jahrbuch fir Numismatik tud Geldgesichte 10 (1959-60) 79-90. 
ter estrictamente alegórico de las representaciones, que aludirían a la felicidad de los tiempos, sin relación con personajes o acontecimientos históricos ${ }^{47}$.

La presentación del programa dinástico de Constantino tras la derrota de Licinio se observa bien en la numismática. En 324-25 se emitieron dos series de monedas conmemorativas, una de oro iniciada en Nicomedia con las efigies de los miembros masculinos de la familia (Constantino Augusto, Crispo, Constantino II y Constancio Césares ${ }^{48}$ ) y otra de bronce -el metal de mayor difusión- en Antioquía, que incluía a Helena y Fausta con el nuevo título de Augustas y que fue repetida en todas las cecas de Oriente y Occidente ${ }^{49}$. La elección de las leyendas y las imágenes de los reversos es muy ilustrativa del papel que se asignaba a cada una de las mujeres en la dinastía. En las monedas de Helena predomina la leyenda SECVRITAS REIPVBLICE (sic): se representa a Helena como Securitas, en pie, mirando a la izquierda con una rama en la mano izquierda y levantando el pallium con la mano derecha, en alusión a su status de cabeza de la dinastía. Mientras que Fausta se asocia con SALVS y SPES REIPVBLICAE, en su calidad de madre que da herederos al emperador y el imperio. La imagen que acompaña a las leyendas habla por sí misma: la emperatriz sostiene en sus brazos a dos niños. En honor de Fausta se acuñaron tambien medallones de oro en Tréveris con la leyenda PIETAS AVGVSTAE: la emperatriz se representa sentada en un trono con un niño en brazos, rodeada de Felicitas, Pietas y cuatro genios, y nimbada, en clara asociación con la divinidad ${ }^{50}$; en conexión con este medallón se encuentra un múltiplo de Crispo del 324, donde se representa a Fausta en el reverso en medio de dos césares togados (Crispo y Constantino II) con las manos unidas, rodeados de la leyenda FELIX PROGENIES CONSTANTINI AVG ${ }^{51}$. A la muerte de Licinio, su viuda Constancia se reintegró en el linaje constantiniano y, aunque no recibió el título de Augusta, fue conmemorada en la numismática como NOBILISSIMA FEMINA SOROR CONSTANTINI AVGVSTI, asociada a Pietas Publi$c a^{52}$.

El lenguaje de las monedas tiene su correspondiente en las inscripciones. Se han conservado ocho epígrafes de Helena, donde en todos los $\operatorname{casos}^{53}$ se

47 Así, M. Cagiano De Azevedo, "Ritratti o personificazioni le figure del soffito dipinto di Treviri?", Archeologia Classica 10 (1958) 60-63.

${ }^{48}$ RIC, VII (Bruun), pp. 53 ss., 618-619.

49 Ibid. pp. 53 ss., 686-687.

50) RIC VII, pp. 203-204.

31 RIC VII, p.203.

${ }^{52}$ RIC VII, p. 57I, no.15.

s7 Excepto en uno: CIL VIII 1633.

La Personalidad Internacional de los Papas Hispania Sacra 48 ( 1996 ) 
pone de relieve su carácter de genetrix y avia de la dinastía ${ }^{54}$. De Fausta, quien tras su asesinato fue condenada a damnatio mentoriae, sólo sobrevive una inscripción, donde es honrada en calidad de $u x o r^{55}$.

Constantino nombró César a su cuarto hijo, Constante, en 333 y a partir de entonces, sin que se puedan explicar bien las circunstancias que le impulsaron a ello, inició una política de asociación al poder de sus parientes, los descendientes de Constancio Cloro, nacidos de una segunda unión con Teodora ${ }^{56}$. Dalmacio (a.333) y Julio Constancio (a.335) fueron nombrados cónsules ordinarios, censores y patricios; su sobrino Dalmacio II fue nombrado César en 335 y otro sobrino, Hanibaliano III, rey del Ponto. A la vez, los lazos dinásticos se estrechaban con dos matrimonios, el de su hija Constantina con Hanibaliano y el de su hijo Constancio II con una hija de Julio Constancio.

Cuando el emperador murió, en mayo del 337, no estaba claro cuál de las ramas de la familia iba a sucederle. Las dos podían reclamar sus derechos, puesto que ambas descendían del Augustó Constancio Cloro. Y si la unión de éste con la madre de Constantino no era un matrimonio legal - a pesar de que la propaganda presentara a Helena como su esposa y como cabeza de la dinastía-, los descendientes de Teodora eran los únicos de verdad legítimos. No existe una narración detallada de los últimos años del reinado de Constantino, ni del debate que precedió al desenlace fatal - nueve muertos- de los herederos de Teodora. Pero este debate existió, y de él ha quedado una muestra en lo que podríamos calificar de una "guerra de imágenes". Cada una de las ramas sacó a la luz su pasado, conmemorando a sus respectivas abuelas, para entonces ya muertas. Las cecas de Tréveris, Roma y Constantinopla emitieron dos series monetales en honor de Helena y Teodora. Ambas eran honradas como Augustas, aunque no hay ninguna noticia de que Teodora lo fuera alguna vez, ni existen otras monedas suyas aparte de éstas. En los anversos se representan los bustos de cada una con la diadema (la insignia imperial) y la leyenda FL IVL HELENAE AVG/ FL MAX THEODORAE AVG. Los reversos de Helena presentan un tipo nuevo en su numismática: PAX PVBLICA, de pie con una rama de olivo y un cetro. Los reversos de Teodora representan a

$\$ 4$ Recopiladas por J.W. DRIJVERS, op.cit. (1992), pp. 45 ss: gentetrici dn. Constantini Maximi...aviae Constantini et Constanti...caesanm (CIL VI 1134=ILS 709); genetrici d.n. Constantini maximi (CIL VI 1135); Constantini augusti mater eft] avia ...cresarum nostrontm (CIL VI 1136); matri domini nostri Constantini (CIL IX 2446); divi Constantini castissimae coniugi procreatrici $d . n$. Constantini maximi... aviae...C/r/i/s/p/i et Constantini et Constanti... (CIL $\mathrm{X}=\mathrm{ILS}$ 708); matri domini nostri... Constantini et aviae...caesarum beatorum uxori divi Consfantii (CIL X 1483); matri domini nostri...Constantini et aviae dominorun...caesartum (CIL X 1484)

\$s ClL X 678: et nombre de Fausta (así como el de Crispo) fue borrado y sustituido por el de Helena, mientras que UXORI se sustituyó por MATRI.

56 Vid. T.D. BARNES, Constanine and Eusebitus, Harvard Univ. Pr., 198I, pp.250 ss. 
PIETAS ROMANA, personificada en la emperatriz de pie que lleva un niño en sus brazos, proclamando su carácter de madre de una línea imperial ${ }^{57}$. Desafortunadamente, no se puede establecer con precisión la fecha de estas emisiones. Kent, a quien se suele seguir en este punto, las sitúa entre el 335 y el 339-4058. La cronología que propone para el fin de la emisión, no obstante, tiene poco sentido en el caso de las monedas de Teodora, puesto que sus descendientes habían desaparecido en septiembre del 337. En su monografía reciente sobre Helena, Drivjers ${ }^{59}$, sin aducir ningún argumento al respecto, da una datación entre mayo y septiembre del 337 , una fecha que, si fuera correcta, cuadraría perfectamente con la misión propagandísca que -en este aspecto no hay dudas- cumplieron las monedas póstumas de Helena y Teodora.

\section{LA EMPERATRIZ-AUGUSTA}

El siglo IV fue la edad de oro de los panegíricos y, por primera vez en la historia del Imperio, las mujeres de la familia imperial recibieron el honor de ser alabadas con una laudatio en vida. Desde época republicana era una práctica tradicional que algún pariente próximo pronunciara una oración fúnebre en honor de las mujeres de la nobleza, y así se hizo para las madres, esposas y otras allegadas del emperador ${ }^{60}$. Pero, aunque se trataba de un discurso público, las cualidades objeto de encomio se circunscribían al ámbito privado, sobre todo virtudes domésticas, y en esto el elogio de la emperatriz no se diferenciaba sustancialmente del de cualquier mujer privada.

Las directrices de la retórica en la composición del basilikós lógos, el elogio imperial, no contemplaban la elaboración de un discurso para la emperatriz. En su manual sobre cómo componer elogios ("Peri epideiktikõön"), Menandro, que escribe a principios del siglo IV, recomienda sólo que: "Si la em-

57 Vid, J.P. Callu, "Pietas Romana. Les monnaies de l'impéralrice Theodora". Málanges $P$. Boyancé, Roma, 1974, 141-15], quien pone de manificsto lo raro de esta tipologfa de pietas, una divinidad, por otra parte, común en las monedas que conmemoran el linaje impcrial.

5* J.P.C. KEnT, P.V. HILl, R.A.G. CARSON, Late Roman Bronze Crinage AD 324-498, Londres, 1960, p. 25; RIC VII, p. 568; cfr. J.P. CALLU. (p).cit. nota supra.

59 Op.cit. (1992), p.44.

(1) Vid., en general, W. KIERDORF, Laudatio Funebris. Interpretaionen und Untersuchungen zur Entwicklung des römischen Leichenrede, Meinsenheim am Glanc, 1980. Se han conservado fragmentos de las orariones funebres de César a su tía Julia y de Adriano a su suegra Matidia (ClL XIV 3579). Los textos han sido recopilados por F. VOLLMER. Latuationum fomelyitm Romanomum historia et reliquiarium editio, Jhb. f. class. Phil. Supp] 18, I89I. TH. MOMMSEN, "Grabrede des Kaisers Hadrian auf die älterc Matidia", Gesammelte Schriften I (Berlín, 1905), 422-28, ha restablecido el texto desaparecido. Recopilación de testimonios sobre oraciones a otras emperatrices del alto imperio en H. TEMPorin,, Die Frauen am Hofe Trajans, Berlín, 1978, pp. 168 ss.

La Personalidad Internacional de los Papas

Hispania Sacra 48 (1996) 
peratriz es particularnente digna y honorable, puede mencionársela aquí (a propósito de la virtud de la castidad en el emperador): a la mujer a quien admiró y amó la ha hecho copartícipe de su trono. Respecto a las demás mujeres, sólo sabe que existen ${ }^{\prime 61}$. Los cambios producidos en la mentalidad tardoantigua y en los usos literarios a raíz de la conversión del Imperio al cristianismo explican porqué la práctica de componer un elogio para la emperatriz se convirtió en un hábito aceptable y, más aún, estimulado desde la corte. Las mujeres de la aristocracia occidental y oriental habían participado con entusiasmo en la aceptación de la nueva religión; colaboraban en el patronazgo de la Iglesia y en el apoyo de las acciones de sus líderes; financiaban proyectos y animaban la producción literaria, a la que contribuyen con sus propias aportaciones. Como contrapartida, y cada vez más a medida que avanza el tiempo, recibieron la atención y la estima de la élite eclesiástica y fueron destinatirias de una parte muy considerable de su producción literaria; cartas de dirección espiritual, tratados que teorizaban sobre la vida ascética, sermones, oraciones fúnebres, sus propias biografías ${ }^{62}$. En esta atmósfera de valorización del lugar de las mujeres de las élites en la sociedad, que conllevaba la afirmación de su papel en el seno del matrimonio y la familia, se explica la producción de elogia destinados a ensalzar a la emperatriz y se explica también el nuevo status de la Augusta tardoantigua y los nuevos atributos con que se la representa en la iconografía.

Han llegado hasta nosotros cuatro discursos de distintos momentos del siglo IV, y de características tambien distintas, destinados a elogiar a mujeres de la casa imperial. Dos redactados conforme a los esquemas retóricos clásicos: el panegírico de Juliano a la emperatriz Eusebia (c.356), en prosa y en griego, y el poema en latín de Claudiano a Serena, la esposa de Estilicón en la corte de Milán. Los otros dos textos son cristianos: el elogio de Helena, la madre de Constantino, realizado por Eusebio de Cesarea e incluido en la Vita Constantini $^{63}$ y el más interesante de todos, la oración fúnebre del obispo Gregorio de Nisa a la emperatriz Flaccila, la esposa de Teodosio I, pronunciado en Constantinopla en c.386. Ninguno de ellos es, en el sentido estricto, un basilikós lógos: el elogio de Juliano no es el de un rétor oficial, sino el de un pariente que da las gracias a su protectora; Serena, por otra parte, no era oficialmente una emperatriz, aunque sus contemporáneos la calificaban adecuadamente como la regina de Occidente ${ }^{64}$; el elogio de Helena está incluido en el de su

61 Ed. y trad. D.A. RuSSEL, N.G. WILson, Menander Rhetor; Oxford, I98I, pp. 90-9I.

62 Vid. M. MARCos, Las minjeres de la aristocracia senatorial de Roma en el bajo Imperio (3/2-4/0), Tesis doctoral (microftcha), Univ. Cantabria, 1990 .

$6.3 \mathrm{VC}$ [II $41,2-47$

(n) Vid. Claudiano, Laus Serenae, v. 5 y Vit. Melam, II ("basilisa"). 
hijo, y está destinado, más que otra cosa, a ensalzar la política de éste; Flaccila, en fin, estaba muerta cuando se compuso su encomio. Pero ninguna de estas condiciones les resta valor como documento para conocer el status de la. emperatriz en la corte tardoantigua.

Los panegíricos, como es sabido, tenían una alto significado político ${ }^{65}$. Se pronunciaban con motivo de grandes celebraciones imperiales -elevaciones al trono, aniversarios, consulados, victorias-; su lectura era una ocasión para renovar el consenso de los súbditos y, muy importante, para exponer programas políticos y propagar la ideología imperial. Desde este punto de vista, los elogios de las emperatrices que hemos mencionado tienen un valor desigual. Los de Juliano y Claudiano siguen al pie de la letra las instrucciones de Menandro para un basilikós lógos y respetan el orden de los tópicos: introducción ("proomion"), estirpe ("génos"), circunstancias del nacimiento ("génesis"), infancia y educación ("anatrophé"), hazañas ("práxeis"), epílogo ("epí$\left.\log 0{ }^{16}\right)^{66}$. Ambos son muy esterotipados tanto desde el punto de vista formal como del contenido y, por su dependencia de la tradición, son los menos expresivos de las nuevas realidades. Eusebia y Serena son alabadas por sus virtudes domésticas más que por su posición pública. Sus cualidades, que por el procedimiento de la sýnkrisis se equiparan con las de las heroinas clásicas, corresponden a las de una matrona romana: pudicitia ("sophrosýne"), bondad ("epieikeía") dulzura ("praótes"), fides hacia el esposo, influencia benéfica sobre el carácter de éste, sabiduría ("phrónesis"), sobriedad, belleza. Si en el elogio de Eusebia se mencionan algunas virtudes que son más cívicas que familiares, como la justicia, la filantropía, la equidad, la "timé" hacia la familia (que se traduce en protección y promoción de los parientes), o la generosidad, y aunque la emperatriz es comparada con las grandes reinas del pasado, aquéllas "que dieron más muestras de virilidad que de discreción"67, Juliano reconduce una y otra vez su discurso al terreno privado. Y lo justifica con el siguiente argumento, conforme a la mentalidad tradicional predominante en los medios intelectuales de su tiempo, y particularmente en los paganos: "hay que alabar mejor a Penélope, que cuidó de su hijo y de su suegro, que fue casta y se mantuvo dentro de la casa: ni se ocupó de los campos, ni de las tro-

6s Vid. espec. S. MACCORMACK, "Latin Prose Panegyrics", en Empire and Aftermath (ed. T.A. Dorey), Londres-Boston, 1975, pp.143 ss.

of La Laus Serenae está fragmentada y falta parte de las "príxeis" y cl "cpílogos". Vid. la valiosa introducción a la edición y traducción de F.E. Consolino, Claudiano. Elogio di Serena, Venecia, 1986.

${ }^{67}$ Semiramis, ia mf́tica reina de Asiria, Nitocris, reina de Babilonia, Tomyris, reina de los masagetas...: Juliano, Orat, III, 17.

La Personalidad Internacional de los Papas

Hispania Sacra 48 (1996) 
pas; jamás se le pasó por la cabeza conducir un ejército ni harengar al pueblo; escondió su cara bajo un velo cuando tuvo que hablar a los pretendientes"68.

Los discursos de Eusebio de Cesarea y Gregorio de Nisa tienen un tono sustancialmente distinto. Si bien siguen sujetos a ciertas convenciones en la forma y en el fondo, son mucho más libres y, acorde con las nuevas tendencias literarias en el ámbito cristiano, contemplan a la emperatriz como una más de las grandes benefactoras de la Iglesia, capaces de poner en marcha su potencial económico y sus ingentes influencias. Sus discursos, sobre todo el de Gregorio, más largo y articulado, presentan a la emperatriz como Augusta, la madre o la esposa en quien el emperador ha depositado su confianza, su consejera y copartícipe de la basileía, el poder imperial. Una teoría que no podía ser completamente retórica —aunque, veremos, tampoco puede tomarse al pie de la letra-, sino que debía corresponder de alguna manera con la posición que gozaba la emperatriz efectivamente en la corte.

Helena es la reina viajera, difusora de los nuevos proyectos políticoreligiosos de su hijo, el único emperador del Imperio, destinado a perpetuarlo en su dinastía; es la "evergeta" que despliega su generosidad repartiendo donativos por las provincias al estilo imperial más clásico y la nueva benefactora cristiana que funda iglesias e invierte en obras caritativas, conforme al nuevo estilo constantiniano; es la Augusta reconocida por las tropas, que merece la estima del emperador hasta el punto de poner a su disposición los fondos del erario público. Flaccila comparte estas características esenciales: la piedad y la generosidad cristianas y, lo que conforma el eje central del discurso de Gregorio de Nisa: es la reina que condivide el poder del emperador y su familiaridad con lo divino $y$, junto a las cualidades de las viejas matronas, ostenta las cuatro virtudes cardinales cívicas: filantropía, justicia, piedad y providencia ${ }^{69}$; virtudes de significado polivalente y susceptibles de ser reinterpretadas, como hace Gregorio, en sentido cristiano. Sobre este trasfondo ideológico debemos leer las imágenes en la iconografía de la emperatriz tardoantigua.

$$
* * *
$$

El emperador asociaba formalmente a la emperatriz al poder mediante la concesión del título de Augusta. Si bien durante el Alto Imperio los príncipes confirieron generosamente este rango a sus esposas, madres y hermanas, la

68 Orat. III, 17.

a9 Vid. M.P. CharlesworTh, "The Virtues of a Roman Emperor: Propaganda and the Creation of Belief", Proceedings of the British Academy 23 (1937) 105 ss.; y más recientemente, A. WALlace-Hadrill, "The Emperor and His Virtues", Historia 30 (1981), 298 ss. En el discurso de Gregorio philanthropía ha sustituido a virrus, que es una cualidad exclusivamente masculina. 
ceremonia nunca llegó a convertirse en una rutina. Era el Senado quien hacía la propuesta - seguramente por sugerencia de la corte-, pero no existía ninguna normativa, que sepamos, que regulara el procedimiento. En el Bajo Imperio la concesión del título, que corresponde al emperador ${ }^{70}$, se restringió mucho, sin que exista ninguna explicación aparente: sólo Galeria Valeria, la mujer del Augusto Galerio, fue nombrada Augusta en la Tetrarquía ${ }^{71}$; Constantino confirió el rango a su madre y a su esposa a finales del 324. Ninguno de sus sucesores, ni los emperadores de la dinastía valentiniana, volvieron a hacerlo ${ }^{72}$ hasta que Teodosio retomó la costumbre, que pervivió a partir de entonces sin interrupción en el Este, pero no así en el Oeste.

Desconocemos todo acerca de la ceremonia de elevación de la Augusta la descripción del ritual que ofrece Constantino Porfirogeneta es demasiado tardía para encontrar paralelos-, y lo que es más importante, no sabemos cuáles eran con exactitud los cambios que introducía el título en el status de la emperatriz ${ }^{73}$. Desde el punto de vista institucional su posición no se modificaba: ta Augusta podía ser muy influyente - como sabemos que lo fue Helena con respecto a Constantino, Flaccila con Teodosio, o aún más Eudoxia con Arcadio y Pulqueria con su hermano Teodosio II-, podía incluso llevar en ciertos momentos las riendas del imperio - como Pulqueria durante la minoría de edad de Teodosio II, o Gala Placidia durante los primeros años de gobierno de su hijo Valentiniano $\mathrm{II}^{74}$ - pero ni la no-Augusta ni la Augusta firmaban, por ejemplo, las leyes. Veremos enseguida cómo en honor de la Augusta se acuñan monedas, se distribuyen estatuas por las provincias junto con las de

711 Por lo menos así cra, sin duda, en el siglo V: Valentininno lll privó a su hermana del cetro de! Imperio (Ptisc., Frag. 15); Honorio y Constantino IIl hicieron Augusta a Gala Placidia (Olimp. Frag. 34), etc.

${ }^{1}$ Según D. KIENAST, Römische Kaisenabelle. Grundzïge einer römische Kaiserchronologie. Darmstadt, 1990 , p. 55-56, csic hecho podría deberse al bajo nivel social al que pertenecían las mujeres de los tetrarcas. Pero esie argumento no sirve para explicar los demás casos del siglo JV.

72 Según A. CAmeron, J. LONG, Barbarians and Polinics at the Court of Arcadius, Univ. California $\mathrm{Pr}$, , 1993, p. 170, n. 85, la caușa de csta interrupción pudo scr la circunstancia particular de la muerte de ta Augusta Fausta, h madre de la dinastíi, asesinada por sospechas de aduiterio. La explicación es, por lo menos, factible.

73. Ningún esfuerzo por clarificar estc aspccto ba dađo resultado. Vid., por ejemplo, S. MASLEV, "Die staadtsrechtliche Stellung der byzantinischen Kaiserinnen", Byzantinoslavica 27 (1966) 308-43. $\mathrm{Ni}$ siquicra queda claro en el jibro de K. Hotum, op.cit. (1982), a pesar de sus incansables esfuerzos por poner de relieve el alto significado del título. Según Eusebio de Cesarea, la elevación al augustado de Helena conllevó el privilegio de ser honrada con monedas y de acceder al tesoro público. Pero sabemos, por ejemplo, que cn esta época no cra un requisito imprescindible ser Augusta para acuñar monedas: Constancia, la hermann de Constantino, aparece en sus monedas con cl títuto NOBILISSIMA FEMINA (RIC VII, Cohen, p. 570: AES emitidos en Constantinopla).

${ }^{4}$ Aunque para ejercer influencia no era preceptivo ser Augusta: así el caso de la poderosn Justina. madre de Valentiniano ]l, en la corłe de Milán.

La Personalidad Internacional de jos Papas Hispania Sacia 48 (1996) 
todos los demás augustos, cómo su efigie sagrada copreside en los lugares oficiales.

El territorio sobre el que reina la Augusta se extiende, según la retórica de la corte y el lenguaje de las inscripciones, por toda la "oikoumene"75, al igual que, formalmente, el de cualquier emperador legítimo. Pero la realidad era bien distinta. El reconocimiento oficial de la Augusta tenía un ámbito geográfico limitado: la parte del Imperio bajo el dominio del Augusto al que está asociada. Así lo muestran las cecas de emisión de sus monedas: las acuñaciones de Helena y Fausta posteriores al 324 proceden de todo el imperio; las de Flaccila y las restantes mujeres de la dinastía Teodosiana sólo de las cecas de oriente. Cuando Arcadio, un gobernante notoriamente débil, envió a Occidente laureatae de su influyente esposa Eudoxia con ocasión de la elevación de ésta al augustado ( 9 de Enero del 400 ), como se hacía habitualmente cuando se nombraba un nuevo Augusto, la corte de Honorio las rechazó por considerar que ésa era una innovación intolerable ${ }^{76}$. Hay que tener en cuenta, no obstante, que en ese momento las relaciones entre ambas cortes eran tensas y también que hacía más de un siglo que no se asistía a la ceremonia de elevación de una Augusta en Occidente.

A parte de elevar el prestigio en la corte y ante los súbditos, el augustado confería a la emperatriz algunos privilegios que sólo se pueden reconocer a través del lenguaje de las imágenes. En honor de la Augusta se acuñan monedas, sus simulacra presiden los lugares oficiales y son objeto de adoratio. Pero el augustado conlleva otros derechos más sutiles, que desempeñan una importante función de propaganda de la monarquía y la dinastía imperial. Asociada formalmente a los poderes del Augusto, la emperatriz asume los aspectos externos de la realeza y los símbolos de su carácter sagrado, recibe honores y exhibe las virtudes imperiales colaborando eficazmente en la creación de consenso.

En el Bajo Imperio se perdió la costumbre de representar a la pareja imperial en las monedas, una imagen que podría haber simbolizado gráficamente mejor que cualquier otra la koinonía a la que se refería Gregorio de $\mathrm{Nisa}{ }^{77} . \mathrm{Ni}$ siquiera, parece, era habitual hacerlo con motivo del matrimonio, que brindaba una ocasión privilegiada para hacer propaganda de la concordia, una virtud

75 Vid. Gregorio de Nisa, OratFlace., PG 46881 n-d (Jaeger, pp. 477-79). 884a (Jaeger, pp. 479-80). Inscripciones: CH. BORNER- R. MERKELBACH, Die Inse'hiffen von Ephicsos, Vol. 1l, Bonn, 1979, n. 314 ("ten déspoinan tes oikoumé(nes)") (Efeso); idem. REG 19 (1906), p. I10, n. $130=$ ILS 9466 (Afrodisias). 38,1 .

${ }^{36}$ Epistulae imperatorum pentificitm, Coll.Avell., CSEL 35 (ed. O. Günther, Vienn, 1895), no.

7 Orat. Flacc., PG 46881 ( (Jaeger, p. 478). 
tantas veces expresada en las monedas que conmemoran el colegio imperial. Sólo en dos ocasiones, eso sí, muy significativas, se revivió la vieja costumbre. La primera con motivo del matrimonio de Licinia Eudoxia, la hija de Teodosio II, el emperador del Este, con Valentiniano III, el Augusto de Occidente, celebrado en 437 . La unión, que había sido pactada trece años antes como símbolo de la reconciliación entre Gala Placidia y Teodosio II y como parte del protocolo de la elevación al augustado del hijo de aquélla, Valentiniano III, suponía la restauración de la unidad de las dos partes del Imperio (aunque oficialmente éstas nunca se habían escindido) en un momento en que Occidente era ya, en realidad, dominio bárbaro. En el anverso de las monedas conmemorativas se representaba a Teodosio II y en el reverso la escena del matrimonio, en la que actuaba como oficiante el emperador, que une las manos de los esposos ocupando el lugar tradicional de Juno Pronuba. La leyenda del reverso se expresa por sí misma: SALVS ORIENTIS FELICITAS OCCIDENTIS $^{78}$,

Una serie monetal semejante a ésta se acuñó con motivo del matrimonio de Pulqueria, que hasta entonces había permanecido virgen por motivos religiosos, con Marciano en 450: el emperador Teodosio II acababa de morir sin descendientes y, puesto que su hermana la Augusta, que tenía más de 50 años, no estaba autorizada a gobernar, se pactó este matrimonio que garantizaba momentáneamente la supervivencia de la dinastía, pero que no dejó de suscitar reacciones en la corte. En el anverso de los solidi conmemorativos se representa a Marciano Augusto, que había sido coronado por Pulqueria en persona, y en el reverso a la pareja: esta vez el oficiante era Cristo. La leyenda transmite un mensaje de prosperidad: FELICITER ${ }^{79}$.

A partir de la elevación al augustado las imágenes de la emperatriz acompañaban a las del emperador y los demás augustos en los lugares oficiales. Constantinopla, lo sabemos por las noticias de los cronistas bizantinos tardíos, era un escenario de glorificación dinástica al que cada emperador contribuía con la aportación de sus retratos familiares. El Augusteon, una plaza porticada en el lugar del antiguo Tetrastoon, centro del barrio administrativo de la capital, estaba saturado de estatuas y relieves ${ }^{80}$. Constantino le dió este nombre en honor de Helena, cuya estatua fue situada sobre una columna de pórfiro dominando la plaza. Aparte de la de Helena hubo allí cuatro columnas más: una de Costantino con sus tres hijos a los pies, otra de plata de Teodosio I con sus hijos, otra también de plata erigida a principios del siglo $\mathrm{V}$ en honor de Eu-

7 Cohen ${ }^{2}$ Vlll, 218 ss. Vid. el comentario de K. HoLUM, op.cit. (I982) p. 209.

79 Vid. K. HoLum, op. cit. (1982) pp.208 ss.

so Vid. R. JANIN, Constantinople Byzantine. Développentent mbain ef rêpertoire topogrophique, París, $1964^{2}$, p. 59 ss.

La Personalidad Internacional de los Papas

Hispania Sacra 48 (1996) 
doxia, dedicada por el prefecto de la Ciudad, Simplicio, y famosa por haber dado lugar a un serio altercado con el obispo de Constantinopla, Juan Crisóstomo, que culminó en su destierro ${ }^{81}$; y una última dedicada a León el Grande (457-474). En la misma plaza, delante del edificio del Senado se encontraba una estatua de Flaccila, que había mandado colocar Teodosio ${ }^{82}$, y un grupo de bustos de oro representando a Honorio, Teodosio II y Pulqueria, dedicados por el prefecto del pretorio, Antemio, en el año $414^{83}$. El Augusteon es sólo un ejemplo, tal vez el más representativo, de esta exhibición de imágenes imperiales que, en mayor o menor medida, debió afectar a las ciudades más importantes del imperio.

Ciudadanos privados o entidades provinciales, por otra parte, honraban ocasionalmente a la emperatriz, Augusta o no, erigiendo estatuas en su honor en las ciudades. El Senado de Antioquía dedicó estatuas a la emperatriz Eudocia Athenais, la mujer de Teodosio II, cuando ésta se detuvo en la ciudad de camino a Tierra Santa ${ }^{84}$. Se han consevado inscripciones de Helena ${ }^{85}$, Faus$\operatorname{ta}^{86}$, Constancia ${ }^{87}$ (la hermana de Constantino), Flaccila ${ }^{88}$, Termancia ${ }^{89}$ (la madre de Teodosio I), Eudoxia ..., que debían ir acompañadas de las correspondientes estatuas. Desafortunadamente, ninguno de estos retratos ha sido hallado in situ, lo que hace imposible identificarlos con certeza. Criterios estilísticos, modas en el peinado, semejanzas con los retratos sobre monedas se han utilizado aisladamente o combinados en la tarea de identificar a sus modelos, con resultados siempre inciertos. De hecho, aparte del tamaño grandioso, sólo un signo seguro permite identificar a una emperatriz tardoantigua: la diadema imperial. Constantino adoptó este distintivo en sus vicennalia del $325 \mathrm{y}$, aunque no regularmente, se incluyó en los retratos monetales de Helena y

\footnotetext{
81 Por esta razón las referencias a la columna y estatua son muy numerosas en los autores bizantinos. Vid. particularmente Soc. VI, I8. La inscripción, bilingüe, que lá acompañabn aún sc conserva, vid. R. JANIN, op. cit. p. 77 .

${ }^{82}$ Temistio, Or. XIX, 228b (G. Downey).

*3 Chron. Pasch. s.a. 414.

84 Chron. Pasch s.a. 444.

8.5 Vid. supra notn 54.

86 Vid. supra nota 55 .

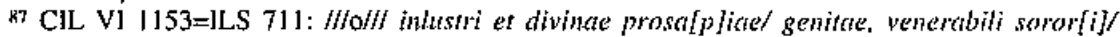
d.n. Constantini Aug. et/ amitaef dd.nn. beatissinorum C[aess] d.n. Fl. Lut. Constanti[ae]/(...).

BR Vid. supra nota 75.

${ }^{29}$ CIL VI 36960, dedicada por el prefecto de Roma, Ceionio Rufio Albino. Para las circunstancias que rodearon a este homenaje, de alto significado político, tras la victoria de Teodosio sobre Máximo, D. VAGLieri, "Iscrizione in onore della madre di Teodosio Magno", Bull. Comm. Arch. Rom. 30 (1902) 256-263.
} 
Fausta $^{90}$. La emperatrices de época teodosiana y sus sucesoras bizantinas siguieron, ya con regularidad, la misma costumbre en la iconografía oficial.

La diadema era el signo más importante de distinción en la iconografía imperial, pero las emperatrices asimilaron otros por mimetismo con la figura del emperador. El oro y la púrpura eran distintivos reales, y toda la familia, incluidos los niños ${ }^{11}$, los Ilevaba en las apariciones públicas. El traje oficial de la Augusta es la clámide o paludamentum, abrochado con una fíbula de piedras preciosas sobre el hombro derecho, un hábito militar idéntico al que portan los retratos de los emperadores en tiempos de paz, y completamente anacrónico, puesto que en el Bajo Imperio la emperatriz había perdido toda relación en la propaganda oficial con el ejército: la última mujer en cuyo honor se acuñaron monedas con la leyenda MATER CASTRORVM, que se habían puesto muy de moda en el siglo III a partir de los Severos, fue Galeria Valeria. La adopción de esta imaginería militar, al igual que la de la Victoria, omnipresente en la iconografía del emperador y representada a menudo en los anversos de las monedas de las augustas, sólo se justifica por esta asimilación calculada de su figura con la del augusto.

De la misma forma que a la corte de Honorio le escandalizaba la idea de recibir las laureatae de Eudoxia, los contemporáneos no podían ver con buenos ojos estas innovaciones en la ideología imperial que, en realidad, reflejaban la evolución de los tiempos, en los que se asistía a una presencia cada vez más visible de las mujeres en los "affaires" político-religiosos de las grandes ciudades, como Constantinopla, Roma o Milán. Si había que aceptar las nuevas realidades —opinaban los intelectuales romanos - debían respetarse al menos las formas. Así, una ley de Valentiniano I del año 370 prescribe que, en caso de que un pretor designado muriera antes de ofrecer los juegos, sus herederos tendrían que hacerse cargo de los gastos. Si no hubiera varones, asumirían la responsabilidad las hijas. Ahora bien, el legislador, precavidamente, advierte que pagar los juegos no autorizaba a las mujeres ad laticlavum atque insignia procedere ${ }^{92}$, esto es, a apoderarse de los símbolos del cargo. Algunas invectivas en la Historia Augusta se explican en este contexto. La reina Zenobia, por ejemplo, es admirada por su cultura, sus dotes para la administración y su habilidad política, pero se deplora su exceso de audacia: "Tras la muerte de su marido Odenato, se echó sobre sus hombros la túnica imperial... y tomando incluso la corona, ejerció el poder imperial en nombre de sus hijos... Esta osada mujer asumió las funciones de un monarca, durante el tiempo

\footnotetext{
Wh Vid. J.W. DRIVJERS, op.cit. (1992) p. 42

\$1 vid. Claudiano. IV Coms. Hon., vv. 205 ss: Teodosio l se paseaba con sus hijos vestidos de oro y coronados en un carro por Constantinopla.

"2 CTh. V1, 4, 17 .

La Personalidad Internacional de los Papas

Hispania Sacra 48 (1996)
} 
en que gobernaba Galieno y más tarde con Claudio"93. Tras los capítulos dedicados a las mujeres ${ }^{94}$, en el apartado sobre los Treinta Usurpadores, el autor de la Historia Augusta concluye: "Ha sido con un propósito deliberado por lo que he incluido a las mujeres; a saber, burlarme de Galieno, el mayor de los monstruos que ha soportado el Estado Romano (...". ¿Podríamos, tal vez, hallar en estos pasajes una alusión velada a las influyentes mujeres de la casa teodosiana, cuyos emperadores eran notoriamente débiles?

Los aspectos externos, el ceremonial en las apariciones del emperador ante el pueblo, el ritual de corte, cada vez más complicado a medida que avanza el tiempo, adquirieron una gran importancia en la presentación de la monarquía tardoantigua ${ }^{95}$. El palacio es un recinto sagrado e inaccesible para el común de los mortales: el cuerpo de guardia, el chambelán y un cortejo de eunucos y cargos administrativos bloquean el acceso directo al monarca. Las habitaciones de la Augusta son también sacrum cubiculum, y bajo los arcos que simbolizan el palacio imperial se la representa a veces en las monedas; posee sus eunucos y su propio "staff", que incluye a los administradores de su patrimonio personal, disperso por distintos lugares del Imperio ${ }^{96}$. Posee una guardia "de corps" que la protege y la hace inaccesible. "¿ Buscas a la emperatriz?" - arengaba Gregorio de Nisa en la oración fúnebre de Flaccila- "pasa la vida en palacio. ¿Deseas verlo con tus propios ojos? No te está permitido llevar a cabo este trabajo inútil de ver a la reina. Está custodiada por un terrible círculo, el de los armigeri ("doryphoroi")"97. La presencia hierática y distante en las "epifanías", el inmovilismo y la inexpresividad de los rostros, que se refleja tan bien en el arte imperial del bajo imperio, forma parte de la aureola de misterio que rodea a la persona imperial. Cuando Juliano pudo ver por primera vez en una audiencia en palacio a su protectora Eusebia se quedó sobrecogido: "Y yo, desde que estuve ante su presencia, creí ver, como en un templo, la estatua erigida de la modestia; el respeto se apoderó de mi alma y mis ojos se fijaron en tierra durante un buen rato hasta que ella me dio ánimos"98.

\footnotetext{
9.3 HA 30 ,

${ }^{94}$ Zenobia y Victoria (cap. 30 y 31 ). A esta última se la hacít responsabic del nombramiento de varios usurpadores galos.

9s Vid. recientemente R. TEjA, "Il ccrimoniale imperiale". en Storia di Roma Einaudi. Vol. 3: L'Eià tardoantica. I: Crisi e trasformazioni, Turín, 1993, pp. 613-42.

9s Vid., p.e., CTh. XIII, 1, 21, sobre el pago de la lustralis collatio por parte del personal de servicio de Pulqueria Augusta; o las noticias a cerca de Flavius Strategius, quien, aparte de otras funciones, estaba encargado de administrat las propiedades de Elia Eudocia en Oxyrrinco: The Oxyrhynch Papyri, vol. L (ed. y trad. A.K. BowMAN, Londres, 1983), pp. 209-210.

${ }^{97}$ Orat. Flact. PG 46888 a (Jaeger, pp. 483-84).

58 Or. III, 123a-b.
} 
Entre las incontables virtudes que Gregorio de Nisa encontraba en Flaccila estaba la de saber combinar a la perfección la accesibilidad con la distancia ${ }^{99}$. Así, desprovista de rasgos personales, se representa a la emperatriz en el arte, hasta el punto de que sólo en las monedas, porque llevan inscrito su nombre, se la puede identificar. Pero la estereotipación de las fisonomías y la continuidad en los atributos -por ejemplo en el tipo de peinado- desempeñaba su función, al igual que en el caso de los emperadores. En los panegíricos los herederos imperiales siempre se parecen a sus padres y la semejanza física en el arte era así una muestra de legitimidad.

La figura de la emperatriz inspiraba el mismo respeto que la del emperador y merecía honores semejantes. Su llegada a una ciudad era ocasión de una ceremonia de adventus: una representación del senado y una muchedumbre de curiosos salían fuera de la muralla para recibir a su reina y escoltarla dentro del recinto; el Senado le rendía honores en la curia, donde la emperatriz pronunciaba un discurso, mientras hacía propaganda de la generosidad imperial repartiendo largitiones al pueblo ${ }^{100}$.

Investida con los insignia de la monarquía, la persona de la Augusta era sagrada; al igual que sus simulacra. A partir de Constantino se difundió la práctica de modelar pesas con la efigie de la emperatriz. Se han hallado un número importante de ellas, procedentes en su mayoría de las regiones danubianas, datables en la primera mitad el siglo $\mathrm{V}$, pero imposibles de identificar (¿Gala Placidia?, ¿Licinia Eudoxia?) -si es que se pretendía reproducir en estos pequeños bustos el retrato de una determinada Augusta. Estas pequeñas figuras encarnaban el poder imperial, servían para poner de relieve la autoridad del emperador sobre los pesos y medidas y, dado su carácter sagrado, eran garantía de honradez en las transacciones ${ }^{101}$.

Producir a las imágenes imperiales alguna lesión era considerado un signo de hostilidad al régimen. En la primavera del 387 estalló un tumulto en Antio-

\footnotetext{
99 Orat. Flace. PG 46884 b (Jaeger p. 480 ).

(in) Una auténtica ceremonia de adventus es la que describe Gregorio de Nisa, cuando el Senado y el pueblo de Constantinopla reciben el cadáver de la emperatriz Flaccila fitera de las murallas (Orat. Flacc. PG 46 885a-b). Vid. reparto de liberalidades, discurso y honores de la curia de Roma a Eusebia (Juliano, Or. Ifl, 19) y Elia Eudocia Athenais en el senado de Antioquía (Chron. Pasch. s.a. 444).

Iot Vid. D. STUTZINGER, "Gewichte in Büstenform", en Spdtantike and frihhes Christenum, Frankfurt am Mainz, 1983, pp. 459-60. El artículo más reciente de E.B. THOMAS, "Bronzebüsten der Licinia Eudoxia in Ungarn", en Rittrato ufficiale $e$ Rittrato privato. Ati della $/ I$ Conferenza Internazionale sul Rittrato Romano, Roma, 1988, pp. 50I-51 1, es meramente descriptivo y no arroja ninguna luz nueva sobre el tema.
}

La Personalidad Internacional de los Papas Hisparia Sacra 48 (1996) 
quía por problemas fiscales ${ }^{102}$. El pueblo se amotinó frente al palacio del gobernador $\mathrm{y}$, como era frecuente, asaltó las imágenes de la familia imperial: primero descolgaron los paneles pintados sobre madera y luego derribaron con cuerdas las estatuas de bronce y las arrastraron por las calles; más tarde prendieron fuego a varios edificios oficiales, entre ellos el palacio imperial. Teodosio, como no era extraño en él, sufrió un ataque de ira y sólo la intervención de personajes relevantes de la ciudad, entre ellos el rétor Libanio, evitó que se infligiera un severo castigo a los antioquenos. Los testigos oculares coinciden en señalar la gravedad de la agresión: se había atacado la imagen del emperador, la de su venerado padre, el divus Teodosio, la de su hijo Arcadio y la de su mujer Flaccila. También la del hijo menor, Honorio, pero, como advierte Libanio, el emperador consideró esta ofensa menos grave pues Honorio aún no había sido nombrado Augusto ${ }^{103}$.

En la Antigüedad Tardía se reafirmó la idea de la asociación del emperador con lo divino y se postularon principios nuevos sobre el origen último de su poder. A partir de la teorización de Eusebio de Cesarea sobre la naturaleza del reinado de Constantino se generalizó la idea de que el emperador era el elegido de Dios, su vicario en la tierra, destinado junto con su dinastía a perpetuar el Imperio cristiano. Las deidades paganas asociadas tan a menudo durante la Tetrarquía a su figura como un alter ego desaparecen gradualmente de la iconografía, a la vez que se incluyen signos nuevos: el crismón y la cruz pasan a formar parte del repertorio de las señas de identidad de la monarquía cristiana. Para subrayar su connivencia con la divinidad, Constantino inició la práctica de autorrepresentarse nimbado y la extendió a las imágenes de los miembros de su familia, incluída su esposa. Múltiplos de Fausta procedentes de Tréveris muestran en el reverso a la emperatriz nimbada, como PIETAS AVGVSTAE, con un niño, Felicitas, Pietas y genios con coronas ${ }^{104}$.

Pero la gran innovación de la iconografía monetal constantiniana, la más osada de todas, fue la dextera Dei: una mano surgía de lo alto con una corona de laurel, que depositaba sobre la cabeza del emperador. La imagen, que cayó en desuso en los años intermedios del siglo IV para revivir con energía en época teodosiana, tiene su paralelo en la representación tradicional, y omnipresente en la iconografía tardoimperial, de la Victoria coronando al empera-

Ia2 Dos testigos oculares dan testimonio de elio, Libanio, espec, Or. XIX-XXIII, y Juan Crisostomo, espec, Hom. XXI, Vid, R, BrowNING, "The Riot of A.D. 387 in Antioch. The Role of the theatrical Claques in the Later Empire", JRS 42 (I952) 13-20. .

${ }^{103}$ Or. XX, 10. Los historiadores de la Iglesia y los cronistas bizantinos transformaton luego la historia y centraton la ira de Teodosio en la afrenta que había recibido su esposa: vid. Teod. de Ciro, HE V, 18-19; León Gramático, Chron., p. 104; Zonaras, X111, 18; Sưid., s,v. "Plakílla".

II) RIC VII (Brunt), pp. 203-204, n. 443-445. 
dor ${ }^{105}$. La imagen de la Victoria, que ponía de relieve los aspectos militares de la monarquía, era poco apropiada para la iconografía de la emperatriz, pero no así la dextera Dei. A partir de Eudoxia, la Augusta se representa también en el arte oficial a Deo Coronata. Sólo un elemento separaba la identidad total de sus atributos icónográficos con los deI Augusto. Sin duda, y a pesar de la evolución de la ideología respecto a la posición de la emperatriz en la corte, fue considerado demasiado audaz representar a la Augusta en actitud de suma majestad, esto es, portando las insigniae y sentada frontalmente en su trono. Pero, aunque fue necesario un largo camino, la escena acabó por ser aceptada y difundida en los reversos de las monedas del siglo V, a partir de Gala Placidia.

Del mismo modo que el ceremonial de la corte y las convenciones en la iconografía del emperador influyeron directamente sobre el ritual cristiano y la representación de Cristo con su corte celestial, la emperatriz tardoantigua dejó la impronta de sus atributos en las imágenes de la Virgen. Nimbada, con el Niño en brazos, rodeada de un cortejo de Santos y ataviada con las joyas y el ropaje de una emperatriz, cada vez más tendente al barroquismo, se representa a María en el arte paleocristiano.

Ins Para estos aspectos, vid, en general S. MACCORMACK, Ant and Ceremony in Late Antiquity, Berkeley-Los Angeles, 1981.

La Personalidad Internacional de los Papas

Hispania Sacra 48 (1996) 